\title{
Fungal Diversity and Over-Represented Non- Nectariferous Plants Pollen in Honey. Case Study on Acacia Honey Authenticity, Analyzed in APHIS Laboratory
}

\author{
Otilia BOBIŞ ${ }^{1}$, Daniel Severus DEZMIREAN ${ }^{2}$, Victoriţa BONTA' ${ }^{1}$, Adriana Cristina URCAN ${ }^{3}$, \\ Adela Ramona MOISE ${ }^{1}$, Rodica MĂRGĂOAN ${ }^{4 *}$ \\ ${ }^{1}$ Life Science Institute, University of Agricultural Sciences and Veterinary Medicine Cluj-Napoca, Romania. \\ ${ }^{2}$ Department of Apiculture and Sericulture, University of Agricultural Sciences and Veterinary Medicine \\ Cluj-Napoca, Romania. \\ ${ }^{3}$ Department of Microbiology, University of Agricultural Sciences and Veterinary Medicine Cluj-Napoca, Romania. \\ ${ }^{4}$ Advanced Horticultural Research Institute of Transylvania, University of Agricultural Sciences and \\ Veterinary Medicine Cluj-Napoca, Romania. \\ *corresponding author, e-mail: rodica.margaoan@usamvcluj.ro
}

Bulletin UASVM Animal Science and Biotechnologies 77(2)/2020

ISSN-L 1843-5262; Print ISSN 1843-5262; Electronic ISSN 1843-536X

DOI:10.15835/buasvmcn-asb: 2020.0009

\begin{abstract}
Pollen analysis is the basic method for the determination of the botanical and geographical origin of honey. However, the presence of over-represented pollen in honeys may lead to false results of the analysis. This can be more severe if this pollen is present in unifloral under-represented honeys of commercial importance (e.g. thyme or acacia honey). In the present study, we investigated the abundance of nectarless pollen grains on several quality characteristics in honey samples. In particular, the physic-chemical (diastase activity, electrical conductivity, sugars and HMF content) analysis were carried out in order to confirm the declared botanical origin. Spectrophotometric method was used for diastase activity determination, electrical conductivity was determined by potentiometry and chromatographic determinations for HMF content (photodiode array detection) and sugars (HPLC refractive index detection). The present study confirms that, in the case of non-nectariferous pollen presence in honeys, a second count must be made, excluding this pollen type and pollen analysis alone cannot give reliable results for the determination of the botanical origin. Consequently, pollen analysis should be combined with other analyses, especially in honeys with under-represented pollens, to give precise results for the botanical characterization and labeling of honeys.
\end{abstract}

Keywords: honey, melissopallynology, non-nectariferous plant pollen, over-represented pollen, physicochemical analysis.

\section{Introduction}

Honey is a natural sweet substance produced by the Apis mellifera bees, from nectar and honeydew, which they collect, combine with own substances and let for maturation in the comb (Council Directive 2001/110/EC). A melliferous plant produces substances that may be collected by the bees and transformed into honey. Melliferous plants are divided into: nectariferous plants, polleniferous plants and mixed plants. Logically, nectariferous plants are the ones with underrepresented pollen, and polleniferous plants are plants with over-represented pollen. 
The plants listed to be with under-represented pollen are: Citrus (10-20\%); Lavandula sp. (1020\%); Rosmarinus (10-20\%); Salvia (10-20\%); Robinia (20-30\%); Tilia (20-30\%) and Medicago (20-30\%). Also Epilobium and some Cucurbitaceae pollens are considered to be under-represented (Louvreaux et al., 1978). As expected, honeys coming from these nectars, will have low number of absolute pollen grains number. Accordingly, monofloral honeys from the above mentioned plants with a high absolute number of pollen grains, must be treated with suspicion, identifying all pollen species and additional chemical analysis are required. On the other hand, different plants are considered to have over-represented pollen. Among these, Myosotis sp., Castanea sativa and Cynoglossum officinale, being considered highly melliferous (Louvreaux etal., 1978). Consequently, honeys from these nectars are expected to have high number of absolute pollen grains number.

A third situation in melissopalynological determination is the presence in high number of non-nectariferous pollens in honeys, which can't be denominated accordingly, thus physicochemical and/or sensory analysis are required. Identification of other pollen types beside those belonging to non-nectariferous plants, leads to the classification of that honey as multifloral, even if it is declared as monofloral by the producer.

According to the principal source of carbohydrates used as raw material, honeys are classified in monofloral (where a certain nectar and pollen type is predominant towards the others present), multifloral (several nectar and pollen source are present in honey in similar amounts) and honeydew (when the carbohydrate source comes from secretion of other parts of plants than nectariferous glands, or excretion of aphides from the leafs and brances of different trees). Authenticity in respect of origin, implies both geographical and botanical origin (Soares et al., 2017; Mădaş et al. 2019). The quality of honey is generally determined by sensory, physicochemical and microbiological analysis (Khalil et al., 2012; Oroian et al., 2016; Bayran, 2019; Tanleque-Alberto et al., 2019; Geana and Ciucure, 2020). Palynology is the basic method for the differentiation of nectar and honeydew honey and monofloral or multifloral honey (Louvreaux et al., 1978; Pita-Calvo and Vázquez, 2016; Rodopoulou et al., 2018). Aditional to melissopalynology, the chemical determinations help in the denomination of certain monofloral honeys (Devillers et al., 2004; Karabagias et al., 2018; Machado et al., 2020) and separation from honeydew honeys.

The aim of the present study was to identify the influence of different fungus and nonnectariferous pollen in under-represented pollen honeys, as well as the influence of beekeeping practices in establishing of honey quality.

\section{Materials and methods}

This case study was realized on two samples of black locust honey samples, analyzed in Laboratory for Quality Control of Bee Products and Bee Diseases from University of Agricultural Sciences and Veterinary Medicine Cluj-Napoca, Romania. The samples were atipic for denominated black locust honey, through the presence of high number of non-nectariferous plants pollen and different types of hyphae and fungus is these monofloral honeys.

Pollen analysis was performed after the method of Louvreaux et al. (1978), using a nonacetolytic method with some modifications in the time and speed of centrifugation for pollen residue preparation. Ten grams of honey were dissolved in $15 \mathrm{ml}$ of $5 \%$ o sulfuric acid in distilled water and centrifuged at $4000 \mathrm{rpm}$ for 30 minutes. The supernatant was removed, leaving about 2 $\mathrm{ml}$ with the pellet. Distilled water was added up to $10 \mathrm{ml}$, shacked and centrifuged for $20 \mathrm{~min}$ at $3500 \mathrm{rpm}$. The operation was performed twice. The final pollen residue from each honey sample was left on a microscope slide in two distinctive drops, dried, stained and fixed with fuchsine in gelatine-glicerine mixture. Light microscopy $(400 \times)$ was used to examine the samples. The pollen spectrum of honey sample was determined by counting 1000 pollen grains using the whole slide if necessary. Relative frequency classes were determined according to the international melissopalynological nomenclature: D - "dominant pollen" (more than $45 \%$ of pollen grains counted), A - "secondary pollen" (representing 15-45\% of the pollen spectrum), I - "important minor pollen" (3$15 \%$ ), R - "minor pollen" (less than 3\%). National legislations in different European countries have established minimal limits for specific pollen, in order to declare the respective honeys as monofloral (Table 1). 
Physic-chemical analysis. Physic-chemical analysis of investigated honey implies water content determination, electrical conductivity, sugar spectrum and HMF content. All these parameters are stated in national standards and international regulations (SR-784/2009; Honey Directive 110/2001).

Water content was measured refractometrically, using the Abbe Refractometer, according to International Honey Commision Analysis Methods (Bogdanov, 2009), by reading the refractive index, making the temperature corrections when necessary. Electrical conductivity was determined potentiometrically, using International Honey
Commision analysis method. Diastase activity was determined using Amylazime as described in International Honey Commision methods. Sugar content determination in the laboratory is made according to International Honey Commision Method, using high performance liquid chromatography and refractive index detection for principal sugars present in honey (Bonta et al., 2008). The HPLC analysis of the carbohydrates is carried out using a modified Alltima Amino $100 \AA ̊$ stainless steel column ( $4.6 \mathrm{~mm}$ diameter, $250 \mathrm{~mm}$ length, particle size $5 \mu \mathrm{m}$ ). The SHIMADZU instrument equipped with degasser, two pumps, autosampler, thermostat oven, controller and refractive

Table 1. Minimum percentage (\%) of pollen required for monofloral honeys in different European countries, according to national legislations (standards, decisions, guidelines)

(SR 784-3/2001; Thrasyvoulou et al., 2018)

\begin{tabular}{|c|c|c|c|c|c|c|}
\hline Honey type & Romania & Croatia & Greece & Germany & Italy & Serbia \\
\hline Arbutus unedo & - & 10 & - & - & - & - \\
\hline Brassica napus & - & 60 & - & 80 & - & - \\
\hline Calluna vulgaris & - & 20 & - & - & - & 20 \\
\hline Castanea sativa & - & 85 & 87 & 90 & - & 85 \\
\hline Citrus spp. & - & $10\left(5^{*}\right)$ & 3 & 20 & 10 & - \\
\hline Gossypium & - & - & 3 & & - & - \\
\hline Erica spp. & - & - & 45 & 45 & - & - \\
\hline Eucalyptus spp. & - & - & - & 85 & - & - \\
\hline Helianthus anuus & 40 & - & 20 & 50 & - & 40 \\
\hline Medicago sativa & - & - & - & - & - & $>30$ \\
\hline Mentha spp. & 20 & - & - & - & - & - \\
\hline Lavandula spp. & - & $10\left(5^{*}\right)$ & - & - & - & - \\
\hline Phacelia tanacetifolia & - & 60 & - & - & - & - \\
\hline Robinia pseudoacacia & $30\left(25^{* *}\right)$ & 20 & - & - & - & 20 \\
\hline Rosmarinus officinalis & - & - & - & - & - & 20 \\
\hline Rubus idaeus & 25 & - & - & - & - & - \\
\hline Salvia officinalis & - & $15\left(10^{*}\right)$ & - & - & - & - \\
\hline Satureja montana & - & 20 & - & - & - & - \\
\hline Taraxacum officinalis & - & - & - & - & - & 20 \\
\hline Thymus spp. & - & - & 18 & - & 15 & - \\
\hline Tilia spp. & 30 & $25\left(10^{*}\right)$ & - & 20 & - & 25 \\
\hline Trifolium spp., Mellilotus spp. & - & - & - & 70 & - & - \\
\hline
\end{tabular}

*With characteristic organoleptic properties of honey for particular plant species (smell, taste, color);

**Differences between superior quality and first class quality. 
index detector. The mobile phase is a mixture of acetonitrile and ultrapure water $(80 / 20 \mathrm{v} / \mathrm{v})$. The injection volume was $10 \mu \mathrm{l}$ and the flow rate was $1.3 \mathrm{ml} / \mathrm{min}$. Calibration curves of pure standards were plotted using the same method, to quantify the sugars separated from honey samples and expressed as $\mathrm{g} / 100 \mathrm{~g}$ honey.

HMF analysis was made following the method described in the International Honey Commission (2009) and validated in APHIS laboratory. The determination uses a Discovery HS C18 $(5 \mu \mathrm{m}$; $4.6 \times 250 \mathrm{~mm}$ ) column, equipped with a C18 precolumn, mobile phases: ultrapure water (solvent A) and HPLC grade methanol (solvent B), injection volume $20 \mu \mathrm{l}$ and $0.8 \mathrm{ml} / \mathrm{min}$ flow rate. Different HMF standard concentrations were used for constructing the calibration curve, in order to quantify HMF from honey samples.

All determinations were made in triplicate, the presented values representing the average \pm SD.

\section{Results and discussions}

Honey samples subjected to this case study were analyzed in APHIS Laboratory to determinate their authenticity. Palinological analysis of the studied honey samples, reveal that the botanical origin declared by the beekeeper do not correspond with the national regulations for monofloral denomination (Table 1 and Figures 1, 2 and 3).
It is known that Robinia pseudoacacia have a flower with under-represented pollen, because is a nectariferous flower. After palynological analysis of these two samples, chemical analysis was made (Table 2), to elucidate the results obtained in pollen analysis.

Analyzing the first acacia honey sample, a very high amount of pollen (absolute number) was identified (more than 25.000 pollen grains). According to von der Ohe et al., (2004) and Louvreaux et al. (1977) honeys are classified according to the total number of plant elements $(\mathrm{N})$ into 5 classes: Class I: $\mathrm{N} \leq 20 \times 10^{3}$ (unifloral honeys with under-represented pollen; Class II: 21 $\mathrm{x} 10^{3} \leq \mathrm{N} \leq 100 \times 10^{3}$, multifloral honeys, honeydew honeys and mixtures of flower and honeydew honeys; Class III: $101 \times 10^{3} \leq \mathrm{N} \leq 500 \times 10^{3}$, unifloral honeys with over-represented pollen and honeydew honey; Class IV: $501 \times 10^{3} \leq 10^{6}$ unifloral honeys with strongly over-represented pollen and some pressed honeys; Class V: N $>10^{6}$ only pressed honey. At first appearance and from palynological point of view, the sample is multifloral, even if the producer denominates it as black locust, as also the $\mathrm{F} / \mathrm{G}$ ratio show this (1.42). The sample have also high content of diastase activity (it is known that acacia honey has, generally, low amount of invertase - diastase activity). The predominant pollen present in the sample belong to Rosaceae family, Filipendula spp. (Figure 1 and 2).

Table 2. Chemical composition (mean \pm S.D.) of the analyzed honey samples

\begin{tabular}{lcc}
\hline \multicolumn{1}{c}{ Parameter } & Acacia declared Sample 1 & Acacia declared Sample 2 \\
\hline Fructose $(\mathrm{g} / 100 \mathrm{~g})$ & $43.60 \pm 2.42$ & $43.11 \pm 3.21$ \\
\hline Glucose $(\mathrm{g} / 100 \mathrm{~g})$ & $30.68 \pm 4.21$ & $32.78 \pm 3.22$ \\
\hline Sucrose $(\mathrm{g} / 100 \mathrm{~g})$ & $0.23 \pm 0.04$ & $3.36 \pm 0.65$ \\
\hline $\mathrm{F} / \mathrm{G}$ ratio & $1.42 \pm 0.21$ & $1.31 \pm 0.03$ \\
\hline Turanose $(\mathrm{g} / 100 \mathrm{~g})$ & $2.43 \pm 0.15$ & $1.07 \pm 0.04$ \\
\hline Maltose $(\mathrm{g} / 100 \mathrm{~g})$ & $1.54 \pm 0.04$ & $2.67 \pm 0.12$ \\
\hline Trehalose $(\mathrm{g} / 100 \mathrm{~g})$ & $0.44 \pm 0.00$ & $0.55 \pm 0.01$ \\
\hline Erlose $(\mathrm{g} / 100 \mathrm{~g})$ & $0.98 \pm 0.01$ & $1.71 \pm 0.21$ \\
\hline Diastase activity $(\mathrm{DN})$ & $24.6 \pm 3.24$ & $14.2 \pm 1.55$ \\
\hline HMF $(\mathrm{mg} / \mathrm{kg})$ & $3.03 \pm 0.56$ & $2.17 \pm 0.23$ \\
\hline Electrical conductivity $(\mu \mathrm{S} / \mathrm{cm})$ & $324 \pm 21.24$ & $486 \pm 31.15$ \\
\hline
\end{tabular}


As far as it is known, Filipendula is a nonnectariferous plant, so we could not have meadowsweet (Filipendula ulmaria) honey. For this reason, a second count was performed, excluding the pollen from the nectarless plant (Filipendula sp.). Following this procedure, low amount of pollen grains was counted, and Robinia pseudoacacia was is a percent lower than the limits for monofloral acacia honey in Romania is established by standard (Table 1), respectively $(<5 \%)$.

Other pollen types, present in the sediment were: Cornaceae - Cornus sanguínea; Rosaceae Prunus spp.; Brassicaceae - Brassica spp.; Gramineae; Plantaginaceae - Plantago; Salicaceae - Salix spp. (Figure 2).

The second acacia sample analyzed in the present study, presented a high amount of fungus and

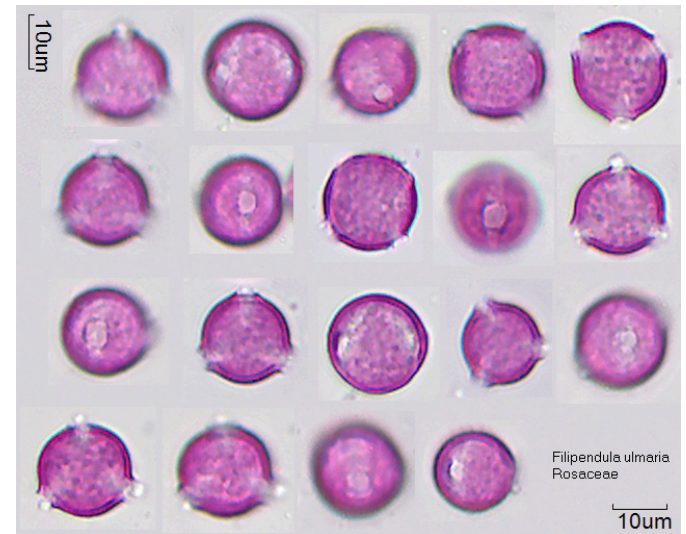

Figure 1. Pollen grains from Filipendula ulmaria (source: http://pollen.tstebler.ch/MediaWiki/index)
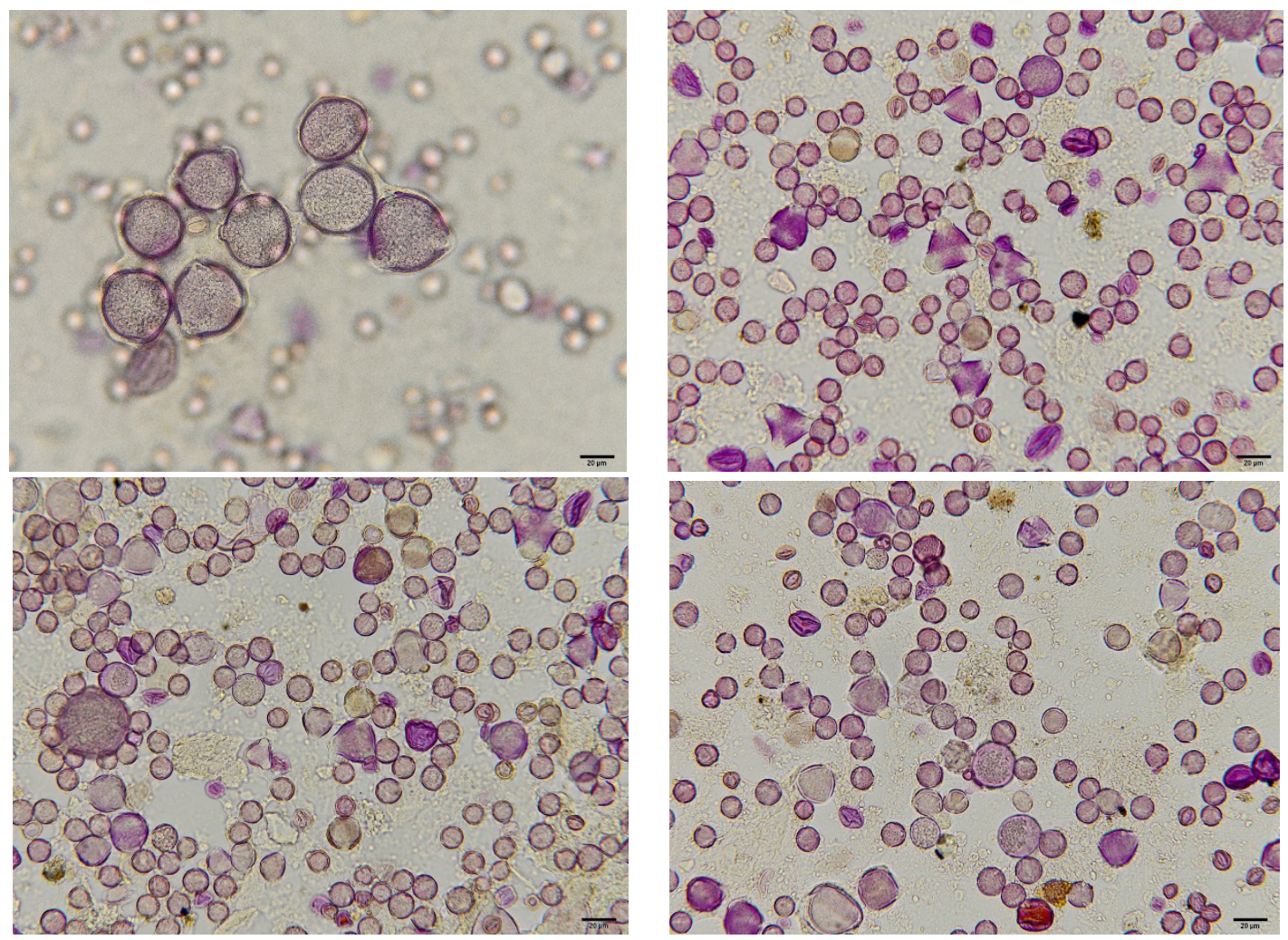

Figure 2. Pollen sediment of first declared acacia honey sample 
hyphae (Figure 3). The origin of the fungus, may be from non-compliance of the good beekeeping practices, or together with a high conductivity, show another denomination for the honey sample (honeydew, not nectar honey) (Seijo et al., 2011). Different types of hyphae were identified in the analyzed sample (Figure 3). These were Metschnikowia cells (this yeast come from nectar itself and there is an interaction of nectar producing plants and flower visiting insects) (Magyar et al., 2005; Herrera et al., 2009; Seijo et al., 2011). Other fungal cells identified in the analysed honey sample was Cladosporium and Alternaria (Seijo et al., 2011). As can be seen in Figure 3, the most abundant fungus is Cladosporium, some conidia found indoor and outdoor environments (Fernández-González et al., 1998; Sabariego et al., 2004). This myxomycete is a saprophytic fungus found also in the alimentary tract of worker honey bees, and probably it came into honey due to second-
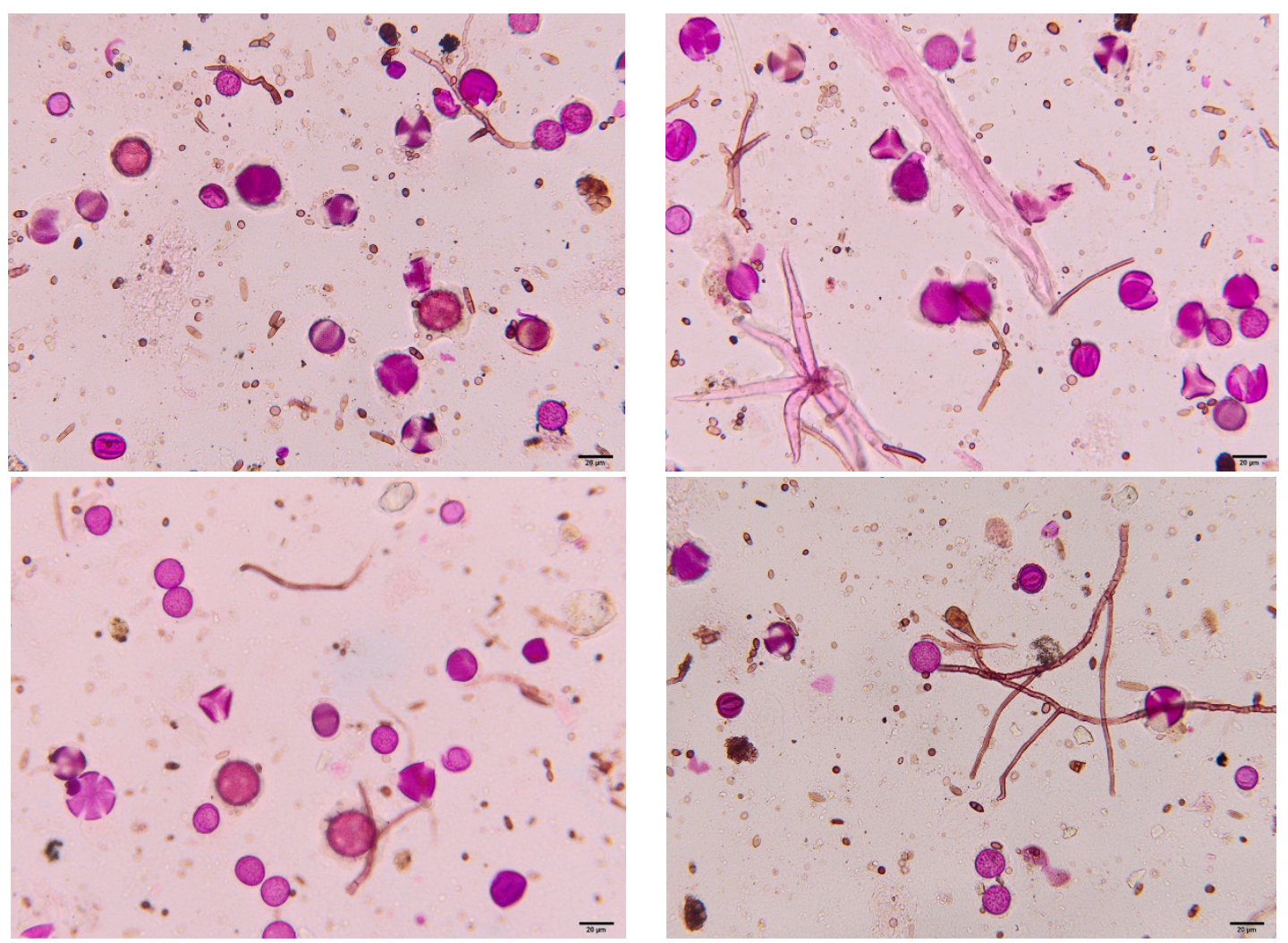

Figure 3. Pollen sediment of the second declared acacia honey sample (2)

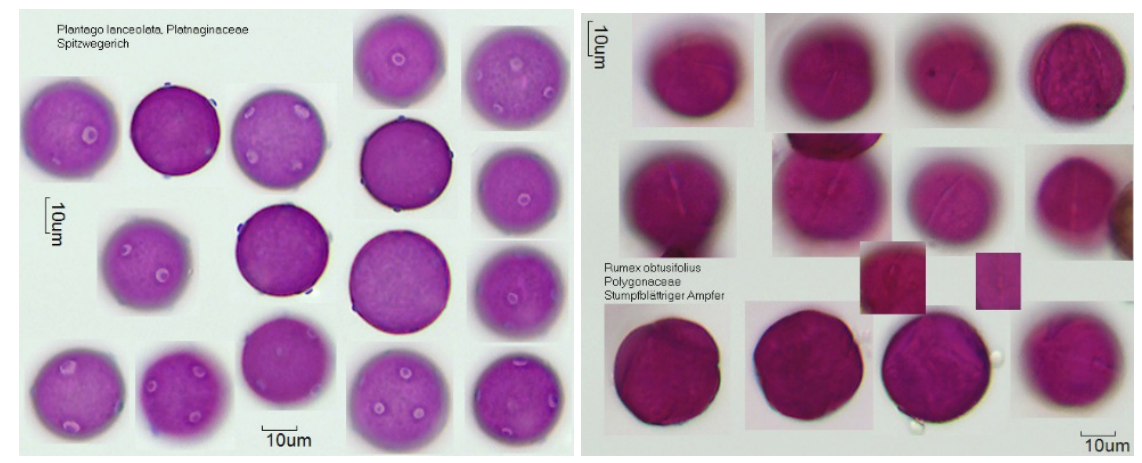

Figure 4. Pollen grains from Plantago lanceolata and Rumex obtusifolius (source: http://pollen.tstebler.ch/MediaWiki/index) 
ary contamination, which may be due to bad beekeeping practices. Also these types of fungus and hyphae were identified by Dimou et al. (2006) in Greek honey and Özkök et al. (2016) in Turkish honeydew honey. The pollen grains identified in this honey belong to: Brassicaceae - Brassica spp.; Polygonaceae - Rumex spp.; Plantaginaceae - Plantago spp.; Caryophillaceae, Rosaceae - Filipendula spp.; Loranthaceae - Loranthus, Gramineae, Tiliaceae - Tilia spp., Cornaceae- Cornus sanguínea and Fabaceae (Figure 3).

Also in the sediment of the second acacia declared honey, pollen from non-nectariferous plants such as Rumex and Plantago were present (Figure 4).

\section{Conclusion}

Monofloral honeys are consumer preferable and more expensive, and for this reason the determination of botanical origin using pollen analysis is very important. The presence of some nectarless pollen in monofloral honeys which are generally from under-represented pollen flowers, may decrease its marketing value.

Also in microscopic analysis, different fungal elements may be identified, being an important parameter for honey origin source determination. If Metschnikowia cells are related to flower honey, different other fungal spores (Cladosporium and Alternaria) are related to honeydew. The presence of these honeydew elements in monofloral spring honey is due to the climatic conditions of the respective beekeeping area, knowing that a high temperature and lack of precipitations, favors the honeydew production.

In conclusion, our study demonstrated, once again, that the combination of microscopic analysis, sensorial and physico-chemical determinations, must be applied as a battery of tests for the correct determination of the botanical origin of monofloral honeys.

Acknowledgments. This research did not receive any specific grant from funding agencies in the public, commercial, or not-for-profit sectors.

\section{References}

1. Balkanska R, Ignatovas M (2013). Physicochemical parameters of Bulgarian rape honey (Brassica spp.) and coriander honey (Coriandrum sativum L.). Proceedings of the $10^{\text {th }}$ International Symposium Modern Trends in Livestock Production, 618-626.
2. Bayram NE (2019). Quality evaluation and pollen profile of honey samples from different locations. Progress in Nutrition 21(4): 928-934. doi: 10.23751/pn.v21i4.8862.

3. Bogdanov S (2002). Harmonised Methods of the International Honey Commision.

4. Council Directive 2001/110/EC relating to honey. Official Journal of European Commission L 164: 1-5.

5. Devillers J, Morlot M, Pham-Delègue MH, Doré JC (2004). Classification of monofloral honeys based on their quality control data. Food Chemistry, 86(2): 305-312. doi: 10.1016/j.foodchem.2003.09.029.

6. Dimou M, Katsaros J, Klonari KT, Thrasyvoulou A (2006). Discriminating pine and fir honeydew honeys by microscopic characteristics. Journal of Apicultural Research, 45: 16-21. doi: 10.1080/00218839.2006.11101319.

7. Geana EI, Ciucure CT (2020). Establishing authenticity of honey via comprehensive Romanian honey analysis. Foos Chemistry, 306, 125595. doi: 10.1016/j. foodchem.2019.125595.

8. Herrera CM, de Vega C, Canto A, Pozo MI (2009). Yeasts in floral nectar: a quantitative survey. Annals of Botany, 103: 1415-1423. doi: 10.1093/aob/mcp026.

9. Karabagias IK, Louppis AP, Kontakos S, Drouza C, Papastephanou C (2018). Characterization and Botanical Differentiation of Monofloral and Multifloral Honeys Produced in Cyprus, Greece and Egypt Using Physocochemical Parameter Analysis and Mineral Content in Conjunction with Supervised Statistical Techniques. Journal of Analytical Methods in Chemistry, ID 7698251. doi: $10.1155 / 2018 / 7698251$

10. Khalil MI, Moniruzzaman M, Boukraâ L, Benhanifia M, Islam MA, Islam MN, Sulaiman SA, Gan SH (2012). Physicochemical and antioxidant properties of Algerian honey. Molecules, 17: 11199-11215. doi: 10.3390/ molecules170911199.

11. Larran S, Ringuelet JA, Carranza MR, Henning CP, Re MS, Cerimele EL, Urrutia M (2001). In vitro fungistic effect of essential oils against Ascosphaera apis. Journal of Essential Oil Research, 13(2): 122-124.

12. Louvreaux J, Maurizio A, Vorwohl G (1978). Methods of Melissopalynology. Journal Bee World, 59(4): 139-157. doi: 10.1080/0005772x.1978.11097714.

13. Machado AM, Miguel MG, Vilas-Boas M, Figueiredo AC (2020). Honey Volatiles as a Fingerprint for Botanical Origin - A Review on their Occurrence on Monofloral Honeys. Molecules, 25: 374. doi: 10.3390/molecules25020374.

14. Mădaş NM, Mărghitaş LA, Dezmirean DS, Bobiş 0 , Ouissam A, Danthine S, Francis F, Haubruge E, Nguyen BK (2019). Labelling Regulations and Quality Control of Honey Origin: A Review. Food Reviews International, 36: 215-240. doi: 10.1080/87559129.2019.1636063.

15. Maghraby AS, Hassan (2005). Effect of antioxidative properties of honey on Schistosoma mansoni-infected mice. Polish Journal of Food Nutrition Science, 14/55(3): 323-326.

16. Magyar D, Gönczöl J, Révay A, Grillenzoni F, Seijo-Coello MC (2005). Stauro-and scolecoconidia in floral and honeydew honeys. Fungal Diversity, 20: 103-120. 
17. Oroian M, Ropciuc S, Buculei A, Pădureţ S, Todosi E (2016). Phenolic Profile of Honeydew Honeys from the NorthEast Part of Romania. Bulletin UASVM Food Science and Technology 73(2): 105-110. doi: 10.15835/buasvmcnfst:12316.

18. Özkök A, Sorkun K, Salih B (2016). The Microscopic and GC-MS Analysis of Turkish Honeydew (Pine) Honey. Hacettepe Journal of Biology and Chemistry, 44(4): 375383. doi: 10.15671/HJBC.2016.117.

19. Pita-Calvo C, Vázquez M (2016). Difference between honeydew and blossom honeys: A review. Trends in Food Science and Technology, 59: 79-87. doi: 10.1016/j. tifs.2016.11.015.

20. Rodopoulou MA, Tananaki C, Dimou M, Liolios V, Kanelis D, Goras G, Thrasyvoulou A (2017). The determination of the botanical origin in honeys with over-represented pollen: combination of melissopalynological, sensory and physicochemical analysis. Journal of the Science of Food and Agriculture, 98: 2705-2712. doi: 10.1002/jsfa.8764.

21. Seijo MC, Escuredo O, Fernández-González M (2011). Fungal diversity in honeys from northwest Spain and their relationship to the ecological origin of the product. Grana, 50(1): 55-62. doi: 10.1080/00173134.2011.559555.

22. Soares S, Amaral JS, Oliveira MBPP, Mafra I (2017). A Comprehensive Review on the Main Honey Authentication Issues: Production and Origin. Comprehensive Reviews in Food Science and Food Safety, 16: 1072-1100. doi: 10.1111/1541-4337.122787.

23. SR-784/2009 Miere de albine.

24. Tanleque-Alberto F, Juan-Borras M, Escheriche I (2019). Quality parameters, pollen and volatile profiles of honey from North and Central Mozambique. Food Chemistry, 277: 543-553. doi: 10.1016/j.foodchem.2018.11.007.

25. Thrasyvoulou A, Tananaki C, Goras G, Karazafiris E, Dimou M,Liolios V,KanelisD, GounariS(2018).Legislation of honey criteria and standards. Journal of Apicultural Research, 57(1): 88-96. doi: 10.1080/00218839.2017.1411181.

26. von der Ohe W, Persano-Oddo LP, Piana ML, Morlot M, Martin P (2004). Harmonized methods of melissopalynology. Apidologie, 35: 18-25. doi: 10.1051/apido:2004050. 